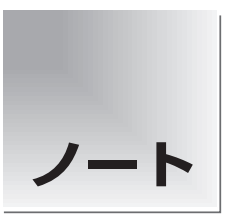

論文受付

2009年5月21日

論文受理

2010年11月6日

Code Nos. 251

\section{実効線量と画像の物理特性による歯科用コーンビーム CT と multi-detector row CT の比較}

\author{
吉田 豊 ${ }^{1)}$ ・徳森謙二 ${ }^{2)}$ ・岡村和俊 2$) \cdot$ 吉浦一紀 2
}

1 ) 九州大学病院医療技術部放射線部門

2)九州大学大学院歯学研究院口腔顎顔面病態学講座

口腔画像情報科学分野

\section{緒 言}

現在, 口腔顎顔面領域の computed tomography (CT) 検査において, 歯科用コーンビーム CT(以下, 歯科用 $\mathrm{CBCT}$ ), multi-detector row $\mathrm{CT}$ (以下, $\mathrm{MDCT}$ ) のいずれも広く利用されている1)。歯や骨といった硬 組織診断用の再構成関数を使用した画像 (以下，硬 組織画像) と, 軟組織診断用の再構成関数を使用した 画像(以下, 軟組織画像)の両方が得られる MDCT と は異なり, 歯科用 CBCT は硬組織の描出を目的とし た装置であり, 安定したCT 值が得られず, 軟組織 の診断は難しい. しかし，その撮影範囲は片側の 3 4 歯を含める数 $10 \mathrm{~mm}$ 程度であり, 解像度, 被曝線 量, 価格, 操作性の面で MDCTより優れていること が報告されている2 。
画像の評価には，物理特性によって評価する物理評 価と観察者による主観的評価である視覚評価がある. 歯科領域に㧈いては, $\mathrm{CBCT}$ と MDCT を物理特性に よって比較を行った報告は見当たらず，歯科用 $\mathrm{CBCT}$ と MDCT の特長をより客観的に明らかにする ことが必要である。ささらに，最近では $100 \mathrm{~mm}$ や 150 $\mathrm{mm}$ を超える広範囲の撮影が可能な歯科用 $\mathrm{CBCT}$ も 存在する。広範囲の撮影における歯科用 CBCT の実 効線量が低線量 MDCT と同程度になる可能性を指 摘した報告 ${ }^{7,8)}$ はあるものの，画質の比較は行われて いない. MDCTにおいても撮影条件を低下させるこ とで線量低減は可能であるが，線量低減は画質の劣 化を伴うため, その画質が臨床に耐えうるものでなけ れば，全く不適切な線量低減となってしまう。した

\title{
Comparison of a Dental Cone Beam CT with a Multi-detector Row CT on Effective Doses and Physical Image Quality
}

\author{
Yutaka Yoshida, ${ }^{1)}$ Kenji Tokumori, ${ }^{2)}$ Kazutoshi Okamura, ${ }^{2)}$ and Kazunori Yoshiura ${ }^{2)}$ \\ 1) Department of Medical Technology, Kyushu University Hospital \\ 2) Department of Oral and Maxillofacial Radiology, Faculty of Dental Science, Kyushu University \\ Received May 21, 2009; Revision accepted November 6, 2010; Code Nos. 251 , 621
}

\section{Summary}

The purpose of this study was to compare a dental cone beam computed tomography (dental CBCT) and a multi-detector row CT (MDCT) using effective doses and physical image quality. A dental mode (D-mode) and an implant mode (I-mode) were employed for calculating effective doses. Field of view (FOV) size of the MDCT was $150 \mathrm{~mm}$. Three types of images were obtained using 3 different reconstruction functions: FC1 (for abdomen images), FC30 (for internal ear and bone images) and FC81 (for high resolution images). Effective doses obtained with the D-mode and with the I-mode were about $20 \%$ and $50 \%$ of those obtained with the MDCT, respectively. Resolution properties obtained with the D-mode and I-mode were superior to that of the MDCT in a high frequency range. Noise properties of the D-mode and the I-mode were better than those with FC81. It was found that the dental CBCT has better potential as compared with MDCT in both dental and implant modes.

Key words: modulation transfer function (MTF), Wiener spectrum (WS), effective dose, dental cone beam computed tomography (dental CBCT), multi-detector row computed tomography (MDCT)

別刷資料請求先： $=812-8582$ 福岡市東区馬出 3-1-1 
Table 1 Recommended tissue weighting factors

\begin{tabular}{lcc}
\hline \hline \multicolumn{1}{c}{ Tissue } & $W_{\mathrm{T}}$ & $\Sigma W_{\mathrm{T}}$ \\
\hline $\begin{array}{l}\text { Bone-marrow (red), Colon, Lung, Stomach, Breast, } \\
\text { Remainder Tissues* }\end{array}$ & 0.12 & 0.72 \\
Gonads & 0.08 & 0.08 \\
Bladder, Oesophagus, Liver, Thyroid & 0.04 & 0.16 \\
Bone surface, Brain, Salivary glands, Skin & 0.01 & 0.04 \\
\hline
\end{tabular}

* Remainder Tissues: Adrenal, Extrathoracic region, Gall bladder, Heart, Kidneys, Lymphatic nodes, Muscle, Oral mucosa, Puncreas, Prostate (male), Small intestine, Spleen, Thymus, Uterus/cervix (female)

がって, 広範囲の撮影が可能な歯科用 $\mathrm{CBCT}$ と MDCT についても, 線量と画質の関係を客観的な指標によっ て明らかにする必要がある。

本研究の目的は, 実効線量と $\mathrm{X}-\mathrm{Y}$ 平面の画像の 物理特性について，狭い範囲だけでなく広範囲の撮 影も可能な歯科用 $\mathrm{CBCT}$ と MDCT とを比較し，歯科 用 CBCT の有用性を明らかにすることである。

\section{1. 方 法}

\section{1-1 使用装置}

歯科用 CBCT として CB MercuRay 9 型(日立メディ コ社製，以下, MercuRay)を, MDCTとして4DAS (data acquisition system)の Aquilion TSX-101A(東芝 メディカルシステムズ社製，以下，Aquilion）を使用 した，実効線量測定には RANDO ファントム (Alderson Research Laboratories)，拉よび蛍光ガラス線量計小 型素子システム Dose-Ace(AGC テクノグラス社製) を用い,リファレンス線量計としてRAMTEC1000 Plus Type 23344(東洋メディック社製)を使用した。解 像特性を表す modulation transfer function(以下，MTF) を求めるために，直径 $50 \mathrm{~mm}$ のシリンジに水を満た して直径 $0.1 \mathrm{~mm}$ のスズワイヤを中心部に張ったワイ ヤファントム(自作)を使用し, 杂隹音特性(ウィナース ペクトル)の評価に直径 $200 \mathrm{~mm}$, 高さ $90 \mathrm{~mm}$ の円柱 形水ファントム(京都科学社製)を使用した。また，歯 科用 CBCT と MDCT のコントラストの違いを考慮して, 水と骨のコントラストスケール99求めるため, コントラ ストファントム(モリ夕製作所社製) と直径 $200 \mathrm{~mm}$, 高さ $120 \mathrm{~mm}$ の円柱型水ファントム(京都科学社製)を 使用した。

\section{1-2 実効線量}

International Commission on Radiological Protection (ICRP) 2007 年勧告 ${ }^{10)}$ で組織荷重係数 (Table 1) が与え られている部位に相当する RANDO ファントム内の 175
カ所を測定部位とした．ガラス線量計素子 (GD-352M) は，読み取り誤差が 5\%以内の素子を用い，RANDO ファントムの測定部位に挿入し，5 回照射後読み取り を行い，1検查あたりの測定值を求めた．ガラス線量 計システムの測定範囲が $10 \mu \mathrm{Gy} \sim 10 \mathrm{~Gy}$ であること から，5回照射で $10 \mu \mathrm{Gy}$ を超えない場合は検出限界 以下として計算に含めなかった.

いずれの装置の線質においても，ガラス線量計素 子とリファレンス線量計の同時照射により校正を行っ た ${ }^{11)}$ 。また，残りの組織に含まれる口腔粘膜と上気道 は同一点の測定值を用い, 皮膚表面，赤色骨髄，骨 表面については川浦ら ${ }^{12)} の$ 方法を，筋肉、リンパ節に ついては Ludlow ら の)の方法を参考に等価線量を求め た。 下顎大臼歯部の検査を想定し, Aquilionでは, RANDO ファントムの咬合平面とスキャン面が平行に なるように位置合わせを行ったうえで，咬合平面から 下顎骨下縁までを含む $51 \mathrm{~mm}$ を撮影範囲とし, FOV (field of view)は $150 \mathrm{~mm}$ とした(Fig. 1). 撮影条件は, 臨床使用の $120 \mathrm{kV}, 150 \mathrm{~mA}, 0.75 \mathrm{~s} / \mathrm{rot}$, ヘリカルピッ チ3.0，撮影スライス厚 $1.0 \mathrm{~mm}$ とした(Table 2). MercuRay では, 撮影範囲が 1 辺 $51.2 \mathrm{~mm}$ の立方体形 となる $\mathrm{D}$ (dental) モード, 直径 $102.4 \mathrm{~mm}$ の球形とな る I(implant)モードを使用した。 Aquilion と同様に下 顎大臼歯部の検査を想定し，Dモードでは左側下顎 第一大臼歯部を中心に， I モードは両側の下顎第一大臼 歯を含むように位置合わせを行った(Fig. 1)，撮影条件 は臨床使用の $120 \mathrm{kV}, 15 \mathrm{~mA}, 9.6 \mathrm{~s}$ とした(Table 2). MercuRay は撮影範囲が直径約 $150 \mathrm{~mm}$ の球形とな る $\mathrm{P}$ (panoramic) モードでも撮影可能であるが，今回 の Aquilion の撮影範囲を考慮すると, 頭足方向に撮 影範囲が広くなるため，比較対象に加えなかった。

\section{1-3 解像特性, 雑音特性}

自作のワイヤファントムおよび直径 $200 \mathrm{~mm}$ の円柱 形水ファントムを Table 2 に示した撮影条件にて撮影 


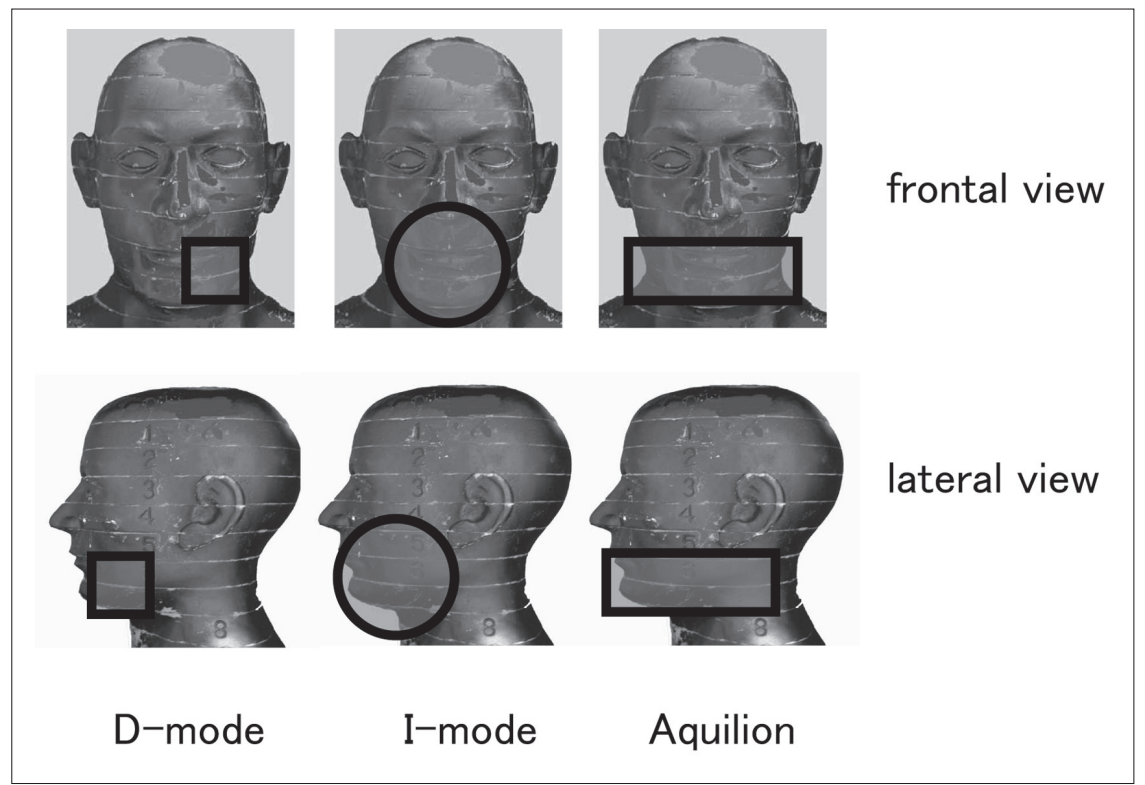

Fig. 1 Positionings of each imaging areas.

Table 2 Scanning parameters

\begin{tabular}{|c|c|c|c|c|c|c|c|}
\hline \multirow[t]{2}{*}{ Aquilion } & $\begin{array}{l}\text { Field of view } \\
\qquad(\mathrm{mm})\end{array}$ & $\begin{array}{c}\text { Tube voltage } \\
(\mathrm{kV})\end{array}$ & $\begin{array}{c}\text { Tube current } \\
(\mathrm{mA})\end{array}$ & $\begin{array}{l}\text { Rotation time } \\
\text { (s/rot) }\end{array}$ & Helical pitch & $\begin{array}{c}\text { Slice thickness and } \\
\text { rows }\end{array}$ & $\begin{array}{l}\text { Scan length } \\
\qquad(\mathrm{mm})\end{array}$ \\
\hline & 150 & 120 & 150 & 0.75 & 3.0 & $1.0 \mathrm{~mm} \times 4$ & 51 \\
\hline \multirow[t]{3}{*}{ MercuRay } & Field of view & $\begin{array}{c}\text { Tube voltage } \\
(\mathrm{kV})\end{array}$ & $\begin{array}{l}\text { Tube current } \\
(\mathrm{mA})\end{array}$ & $\begin{array}{l}\text { Scan time } \\
\text { (s) }\end{array}$ & & & \\
\hline & D-mode & 120 & 15 & 9.6 & & & \\
\hline & I-mode & 120 & 15 & 9.6 & & & \\
\hline
\end{tabular}

した. Aquilionについては, 画像の再構成関数に よって物理特性が異なるため, FC1(腹部用), FC30 (内耳·骨用)および FC81(高精細用)の 3 種類について, スライス厚 $1.0 \mathrm{~mm}$ の画像から MTFとウィナースペ クトル(WS)を算出 ${ }^{13,14)}$ した. MercuRay については, D モードで $0.1 \mathrm{~mm}, I$ モードで $0.2 \mathrm{~mm}$ の厚さの axial 画像(マトリクスサイズ $512 \times 512$ ) から MTF, WS を求 めた。画像解析にはフリーソフトウエアの Image ${ }^{15)}$ 用いた。 また, WS の比較では Aquilion, MercuRay 両者のコントラストが異なるため, 皮質骨と水のコン トラストスケール $(\mathrm{CS})^{9)}$ を算出し補正を行った。 CS の 計算式を(1)式に示す.

$$
\mathrm{CS}=\left(\mu_{\text {bone }}-\mu_{\text {water }}\right) /\left(\mathrm{CT}_{\text {bone }}-\mathrm{CT}_{\text {water }}\right)
$$

ここで $\mu_{\text {bone }}, \mu_{\text {water }}$ はそれぞれ皮質骨と水の線減弱 係数, $\mathrm{CT}_{\text {bone }}, \mathrm{CT}_{\text {water }}$ はそれぞれ皮質骨と水の CT 值 である。 コントラストファントム (Fig. 2)の骨等価樹脂
を皮質骨の值として使用した。コントラストファントム を水ファントム中心部に固定して撮影を行い(Fig. 3)， さらに同様の位置合わせで水ファントムのみを撮影し た. 得られた画像(Fig. 4)の中心部に円形の関心領域 を設定し，骨等価樹脂と水の CT 值を測定した。さら に, 皮質骨と水の質量減弱係数 ${ }^{16)}$ を求め, 密度をそ れぞれ $1.0 \mathrm{~g} / \mathrm{cm}^{3}, 1.5 \mathrm{~g} / \mathrm{cm}^{3,17)}$ として CS を求めた. 補正後の WS $\left(\mathrm{WS}_{\mathrm{mod}}\right)$ は(2)式にて求めた。

$$
\mathrm{WS}_{\mathrm{mod}}=\mathrm{WS} /(\mathrm{CS})^{2}
$$

\section{2. 結 果}

等価線量, 実効線量を Table 3 に示す. Aquilion の実効線量は $1.35 \mathrm{mSv}$, MercuRayはDモードで $0.24 \mathrm{mSv}$, I モードで $0.67 \mathrm{mSv}$ となった.

Aquilionの MTF は FC81 が最も高く, FC30, FC1 の順に低くなった(Fig. 5). 1.14 cycles/mm 以下では FC81 が最も高い值を示したが， 1.15 cycles/mm 以上 ではDモードが最も高い值を示した。また， 0.58 


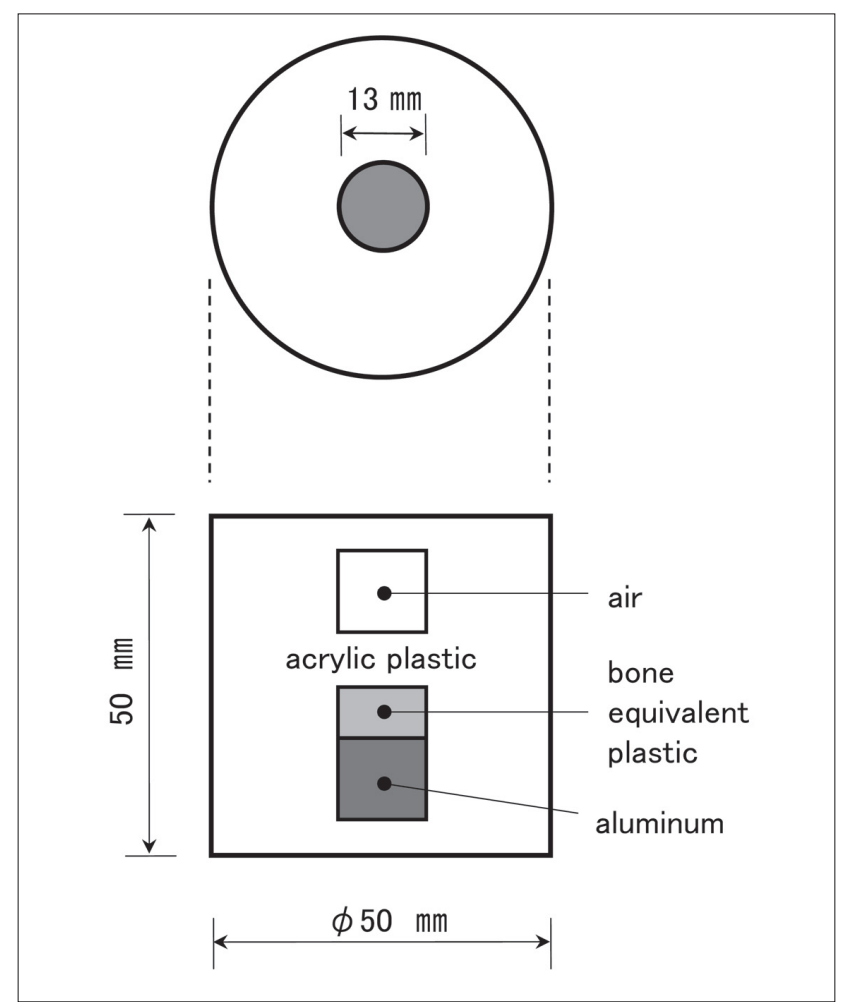

Fig. 2 Contrast phantom.

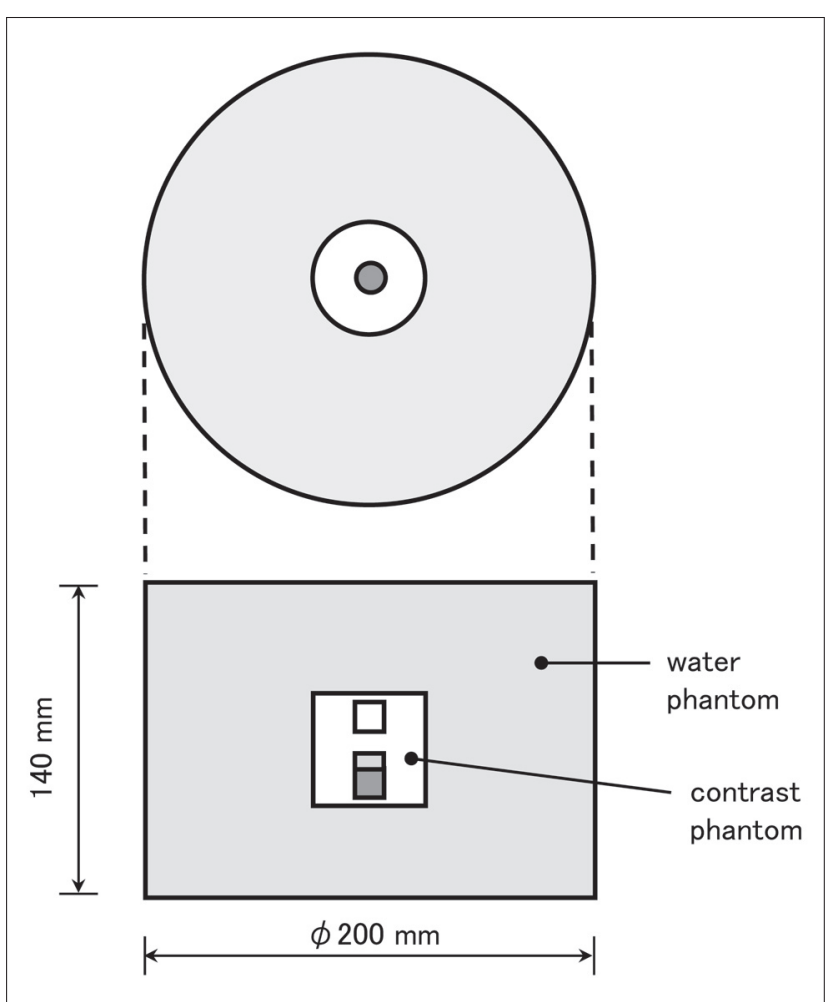

Fig. 3 Contrast phantom fixed in the water phantom.

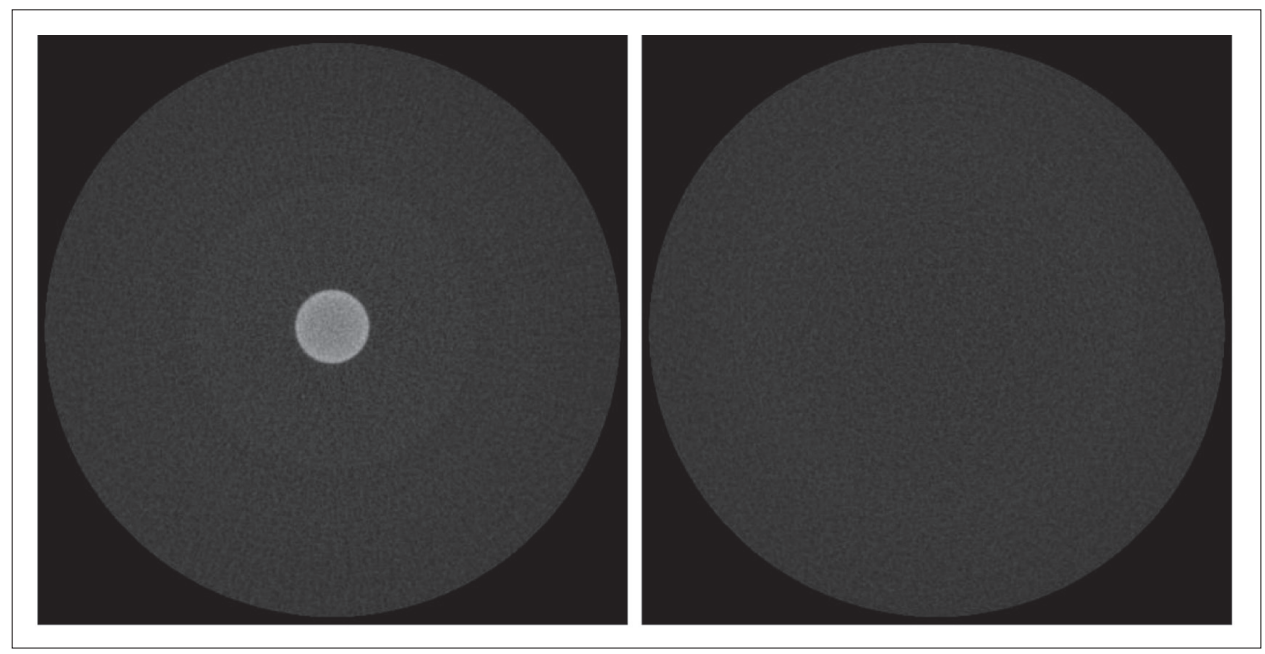

Fig. 4 I-mode axial images.

Contrast phantom in the water phantom (left, bone equivalent plastic image). Water phantom image (right).

cycles/mm 以下では FC30 が MercuRay よりも高く, I モードは 1.24 cycles/mm 以上において FC81 よりも高 い值を示した。

Aquilion の $\mathrm{WS}_{\mathrm{mod}}$ は MTF と同様に FC81 が最も高 くFC30, FC1の順に低くなった(Fig. 6). MercuRay の D モードは, FC81 よりも低く, 0.65 cycles $/ \mathrm{mm}$ 以上 において FC30よりも高い值を示したが, 1.6 cycles/ $\mathrm{mm}$ において FC81 と同等の值を示した。 $\mathrm{I}$ モードは FC81 よりも低く, 0.78 cycles $/ \mathrm{mm}$ 以上において FC30
よりも高い值を示した。また，FC1 が最も低い值を示 した.

\section{3. 考 察}

下顎大臼歯部の検査を想定した比較において, MercuRay D モードの実効線量は Aquilionの 18\%, I モードは $50 \%$ であった. I モードの実効線量が D モードの 2.8 倍となつたが, これは Fig. 1 のような位 置合わせによって I モードの撮影範囲に甲状腺が含 
Table 3 Equivalent dose and effective dose

\begin{tabular}{|c|c|c|c|}
\hline & \multirow[t]{2}{*}{ Aquilion } & \multicolumn{2}{|c|}{ MercuRay } \\
\hline & & D-mode & I-mode \\
\hline Gonads & $<0.01$ & $<0.01$ & $<0.01$ \\
\hline Bone marrow & 1.34 & 0.17 & 0.44 \\
\hline Colon & 0.01 & $<0.01$ & $<0.01$ \\
\hline Lung & 0.32 & 0.03 & 0.08 \\
\hline Stomach & 0.03 & $<0.01$ & 0.01 \\
\hline Bladder & $<0.01$ & $<0.01$ & $<0.01$ \\
\hline Breast & 0.17 & 0.03 & 0.07 \\
\hline Liver & 0.03 & 0.01 & 0.01 \\
\hline Oesophagus & 0.27 & 0.02 & 0.06 \\
\hline Thyroid & 3.34 & 0.74 & 6.96 \\
\hline Skin & 0.99 & 0.13 & 0.41 \\
\hline Bone surface & 3.41 & 0.79 & 1.92 \\
\hline Brain & 3.69 & 0.84 & 2.04 \\
\hline Salivary gland & 30.61 & 4.75 & 10.63 \\
\hline Remainder tissues & 4.94 & 0.99 & 1.37 \\
\hline Effective dose & 1.35 & 0.24 & 0.67 \\
\hline
\end{tabular}

まれたことが大きく影響したと考えられる。実際, Aquilionと Iモードの甲状腺の等価線量は 3.34 $\mathrm{mSv}, 6.96 \mathrm{mSv}$ であり, I モードがAquilionの倍以 上となった。歯科用 $\mathrm{CBCT}$ は任意に撮影範囲を変え ることができず, 数種類の撮影範囲から選択できるよ うに設定されているものがほとんどである。そのた め，検査は必要な範囲よりも広い撮影範囲を選択す ることになる。撮影範囲が広くなれば実効線量は増 加する18〜20) ため，撮影範囲を任意に設定できる機能 を備えることは今後の歯科用 CBCT に求められるひ とつの要素であると考える。ただし, 実効線量は組 織荷重係数の与えられている部位の等価線量に大き く影響を受けるため, 甲状腺や頸椎(骨髄)を鉛で遮 蔽して歯科用 CBCT の実効線量を下げる手法 ${ }^{21)}$ も り, この手法は I モードのような撮影範囲においては 有用であると思われる。また，X線照射口に鉛板を 貼り付けることによっても甲状腺を遮蔽することは可 能であり, 線量低減が可能であると考えられる。

解像特性は 1.24 cycles $/ \mathrm{mm}$ 以上の高周波数領域 で, MercuRayがAquilionよりも高い值を示し, 10\%MTF においては FC81 が $1.29 \mathrm{cycles} / \mathrm{mm}$, I モー ドが 1.48 cycles/mm, D モードが 1.91 cycles/mm で あり, FC81 よりも高解像度である MercuRayの特徵 が明らかになった. AquilionはFC1 が最も低く， FC30, FC81の順に高くなったが, FC30は最大で 1.08, FC81 は最大で 2.17 の值を示した。これに関連 して MTF 測定に用いたワイヤファントムの画像とプ

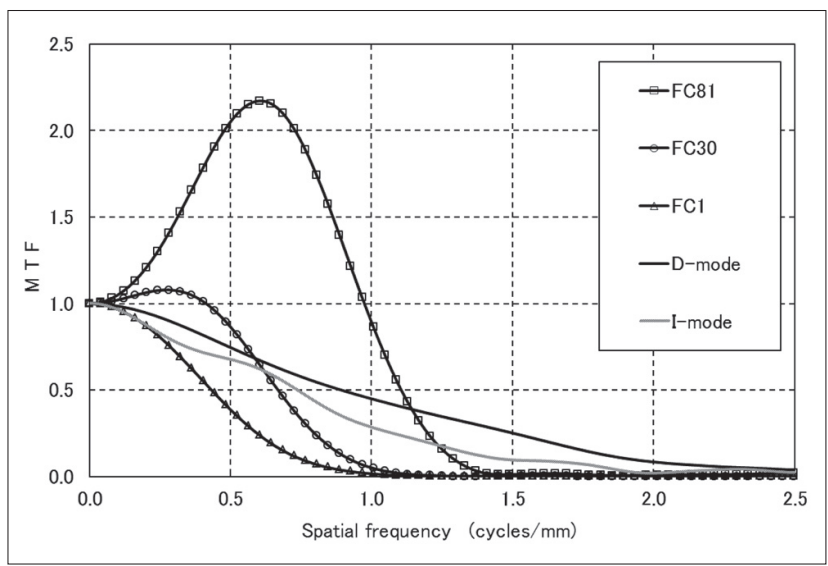

Fig. 5 MTF curves of Aquilion and MercuRay.

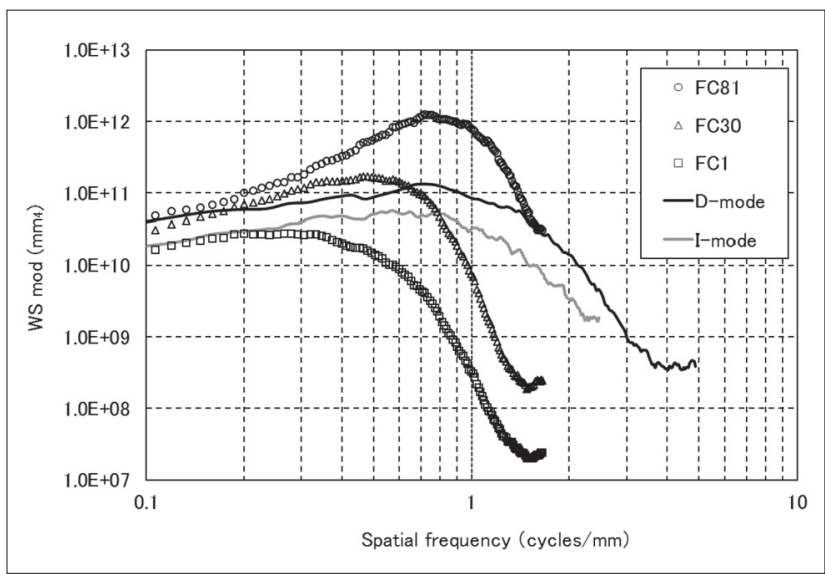

Fig. 6 Wiener spectral values modified by contrast scale.

ロファイルカーブを Fig. 7 に示す.FC30 と FC81 で は, ワイヤと水の境界部分にエッジ強調によるアン ダーシュートが生じており, 特にFC81において顕著 であった。このアンダーシュートの存在がFC30,

FC81の MTF 曲線の形状に影響した。

また, MercuRayのワイヤ像が確実に微小点として 示されていることが, 高周波数領域における MTFの 特性を裏付けており，10\%MTFとこれらのワイヤ画 像から, MercuRayは非常に優れた解像特性を有す ることが示された。

頭部ファントムPB-1 (京都科学社製)を撮影した Aquilionの再構成関数 FC1，FC30，FC81 およびD モード, I モードの axial, sagittal 画像を Fig. 8 に示す. 今回は $\mathrm{X}-\mathrm{Y}$ 方向の検討のみで体軸方向の特性を検 討していないが, MercuRayの優れた解像特性を確 認できる。

皮質骨と水の CS はD モードが $9.68 \times 10^{-4} \mathrm{~cm}^{-1}, \mathrm{I}$ モードが $1.15 \times 10^{-3} \mathrm{~cm}^{-1}, \mathrm{FC} 1, \mathrm{FC} 30, \mathrm{FC} 81$ はそれぞ れ $4.79 \times 10^{-4} \mathrm{~cm}^{-1}, 4.58 \times 10^{-4} \mathrm{~cm}^{-1}, 4.62 \times 10^{-4} \mathrm{~cm}^{-1}$, で 


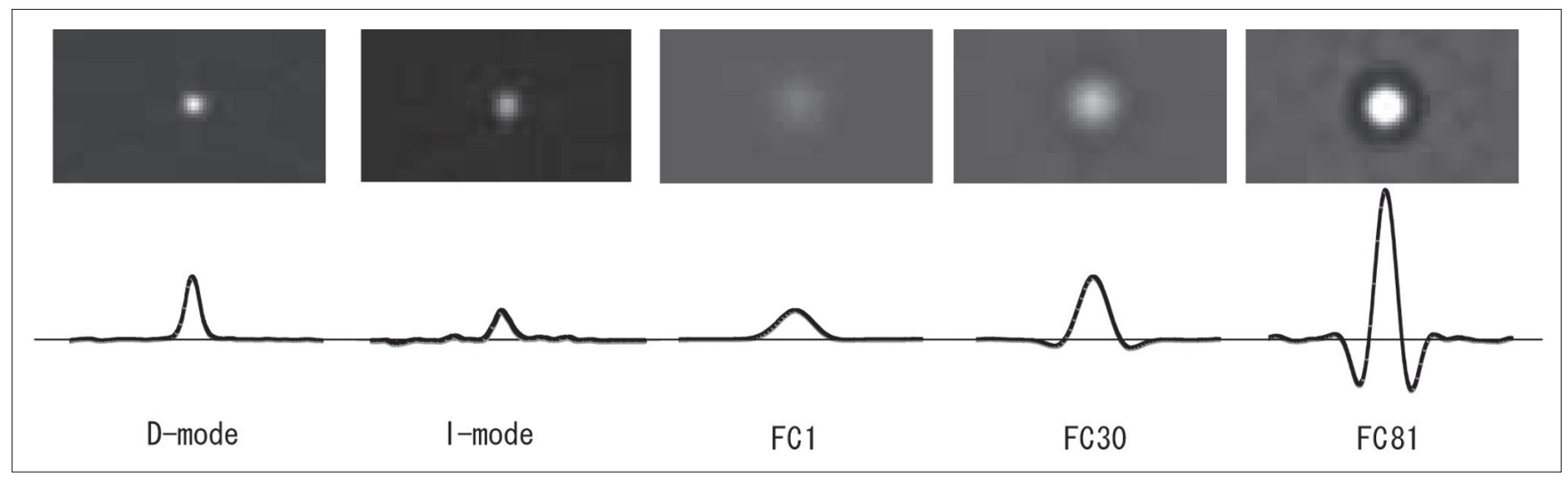

Fig. 7 Stannum wire phantom profile curves.

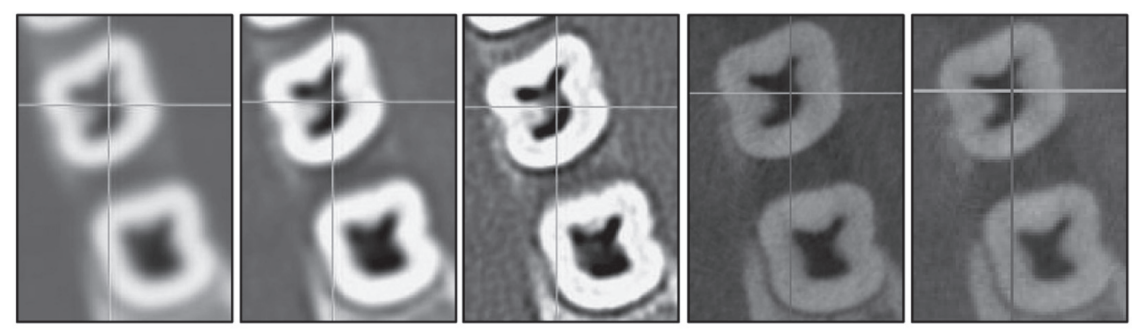

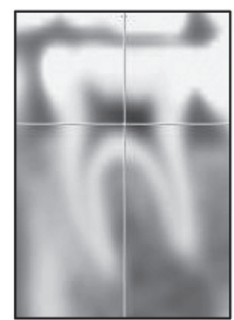

FC1

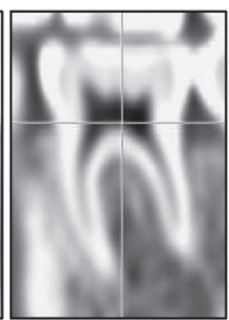

FC30

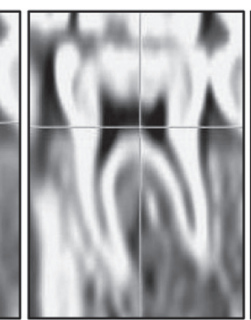

FC81

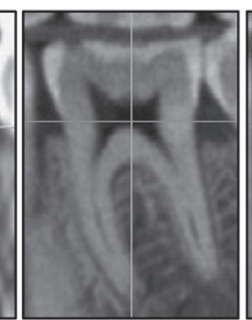

D-mode

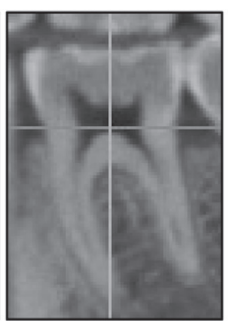

I-mode

(0.5 mm slice thickness)

Fig. 8 Axial and sagittal images of the left mandibular first molar region of the head phantom.
あり，骨と水のコントラストは MercuRayよりも Aquilion が優れていた。 これら CS を考慮した $W_{\text {mod }}$ は，Dモード，I モードともに FC81よりも低い值で あったが, 1.6 cycles/mmにおいてはFC81が $3.06 \times 10^{10} \mathrm{~mm}^{4}$ ，D モードが $3.08 \times 10^{10} \mathrm{~mm}^{4}$ であり，同

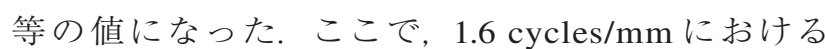
MTF は FC81 が 0.02 未満であるのに対し, D モード は 0.21, I モードは 0.09 である点を考慮すると，高周 波数領域において，Dモード，I モードは Aquilionよ りも有意に信号雑音比に優れることが推測される.

また, Aquilion では歯のエナメル質の CT 值が非 常に高く，特にFC81 においてはエッジ強調の影響も あり, ウインドウレベルとウインドウ幅の調整をして も白レベルへの飽和を余儀なくされ，内部構造を観
察できない。それに対して MercuRayでは内部構造 を観察できる。ダイナミックレンジが画像の視覚評価 に影響を与える可能性も考えられるが，詳細につい ては今後の検討課題である.

\section{結 語}

歯科用 CBCT は低実効線量であるにもかかわら ず，特に高周波数領域において，MDCTよりも優れ た $\mathrm{X}-\mathrm{Y}$ 平面の解像特性・雑音特性を有している。撮 影部位によっては実効線量増加に注意する必要もあ るが，広範囲の撮影が可能な歯科用 CBCT においても， MDCT と比べて低被曝線量・高解像度で硬組織評価 が可能である。臨床目的を考慮し，画像の物理特性 と被曝線量を把握したうえで歯科用 CBCT, MDCT 
のいずれの適応となるか判断することが望ましい.

\section{謝 辞}

本研究に際し，ご協力くださいました九州大学病
院医療技術部放射線部門の皆様，ならびにご指導く たさいました九州大学大学院歯学研究院口腔顎顔面 病態学講座口腔画像情報科学分野の先生方に深く感 謝いたします。

\section{参考文献}

1）新井嘉則. 歯科用コーンビーム CT の留意点. 日歯先技研 会誌 2010; 16(2): 69-74.

2) Arai Y, Tammisalo E, Iwai K, et al. Development of a compact computed tomographic apparatus for dental use. Dentomaxillofac Radiol 1999; 28(4): 245-248.

3) 岩井一男, 新井嘉則, 橋本光二, 他. 小照射野コーン ビームCT 撮影における実効線量. 歯科放射線 2000; 40(4): 251-259.

4) Cohnen M, Kemper J, Möbes O, et al. Radiation dose in dental radiology. Eur Radiol 2002; 12(3): 634-637.

5) Araki K, Maki K, Seki K, et al. Characteristics of a newly developed dentomaxillofacial X-ray cone beam CT scanner (CB MercuRay): system configuration and physical properties. Dentomaxillofac Radiol 2004; 33(1): 51-59.

6) Schulze D, Heiland M, Thurmann H, et al. Radiation exposure during midfacial imaging using 4- and 16-slice computed tomography, cone beam computed tomography systems and conventional radiography. Dentomaxillofac Radiol 2004; 33(2): 83-86.

7) Ludlow JB, Ivanovic M. Comparative dosimetry of dental CBCT devices and 64-slice CT for oral and maxillofacial radiology. Oral Surg Oral Med Oral Pathol Oral Radiol Endod 2008; 106(1): 106-114.

8) Okano T, Harata Y, Sugihara Y, et al. Absorbed and effective doses from cone beam volumetric imaging for implant planning. Dentomaxillofac Radiol 2009; 38(2): 79-85.

9) 日本放射線技術学会編. X 線 CT 検査系. 臨床放射線技 術実験ハンドブック。通商産業研究社, 東京, 1996: 387-390.

10) International Commission on Radiological Protection. ICRP publication 103. Annals of the ICRP 2007; 37(2-4).

11）小宮 勲, 白坂 崇, 梅津芳幸, 他. 蛍光ガラス線量計に
よる患者被ばく線量測定一特性評価と腹部 IVR 時の患者 皮膚線量測定一. 日放技学誌 2004; 60(2): 270-277.

12）川浦稚代，青山隆彦，小山修司。人体ファントム線量測定 に基づいた各種頭部 X 線検査における患者の臓器線量お よび実効線量評価. Radioisotopes 2005; 54(3): 55-66.

13）市川勝弘, 原 孝則, 丹羽伸次, 他. CTに㧈ける金属ワ イヤによるMTFの測定法. 日放技学誌 2008; 64(6): 672-680.

14）市川勝弘, 小寺吉衞, 大橋一也, 他. 等解像度画像を用 いたCT の性能評価. 日放技学誌 2006; 62(4): 522-528.

15) Wayne Rasband. The National Institutes of Health, USA. http://rsb.info.nih.gov/ij.

16) Hubbell JH, Seltzer SM. Tables of X-Ray Mass Attenuation Coefficients and Mass Energy-Absorption Coefficients from $1 \mathrm{keV}$ to $20 \mathrm{MeV}$ for Elements $\mathrm{Z}=1$ to 92 and 48 Additional Substances of Dosimetric Interest. NIST Standard Reference Database, 2004.

17）京都科学. II 医療画像用ファントム。医学看護教育用総 合カタログ MODEL-40. 京都科学, 京都, 2009: 121.

18) Roberts JA, Drage NA, Davies J, et al. Effective dose from cone beam CT examinations in dentistry. Br J Radiol 2009; 82(973): 35-40.

19) Hirsch E, Wolf U, Heinicke F, et al. Dosimetry of the cone beam computed tomography Veraviewepocs 3D compared with the 3D Accuitomo in different fields of view. Dentomaxillofac Radiol 2008; 37(5): 268-273.

20) Palomo JM, Rao PS, Hans MG. Influence of CBCT exposure conditions on radiation dose. Oral Surg Oral Med Oral Pathol Oral Radiol Endod 2008; 105(6): 773-782.

21) Tsiklakis K, Donta C, Gavala S, et al. Dose reduction in maxillofacial imaging using low dose Cone Beam CT. Eur J Radiol 2005; 56(3): 413-417.

\section{| || || || || || |||||||||||||||||||||||||||||||||||||||||||||||||||| 図表の説明}

Fig. 1 各撮影範囲における位置合わせ

Fig. 2 コントラストファントム

Fig. 3 水ファントム中に固定されたコントラストファントム

Fig. 4 I モードのアキシャル画像 水ファントム中のコントラストファントム(左, 骨等価樹脂の画像). 水ファントム画像(右).

Fig. 5 Aquilion と MercuRay の MTF

Fig. 6 コントラストスケールで補正されたウィナースペクトル

Fig. 7 スズワイヤファントムのプロファイルカーブ

Fig. 8 頭部ファントム左側第一大臼歯部のアキシャル画像とサジタル画像

Table 1 勧告された組織荷重係数

Table 2 各種撮影条件

Table 3 等価線量と実効線量 